\title{
DANIEL'S SON OF MAN IN MARK: \\ A REDEFINITION OF THE EARTHLY TEMPLE AND THE \\ FORMATION OF A NEW TEMPLE COMMUNITY ${ }^{1}$
}

Robert Snow

This study attempts to build upon Professor Morna Hooker's work, The Son of Man in Mark, in which she concludes that 'the authority, necessity for suffering, and confidence in final vindication, which are all expressed in the Marcan [Son of Man] sayings, can all be traced to Dan. 7.'2 Starting with an analysis of the Son of Man [SM] in Daniel 7, the dissertation focuses on the priestly aspects of the SM and his presentation in the heavenly temple. In light of this particular OT background, Mark's Son of Man redefines the sacred space of the temple around himself. Initially, the SM does so by manifesting the divine presence. However, the temple leaders eventually cause the SM to suffer and die, through which redemption for Jesus' faithful followers is provided and a new temple community is formed. The SM's manifestation of the divine presence and redemptive suffering death finds vindication at the appearance of the exalted priestly SM who comes in the context of a celestial temple.

The reuse of Scripture as it manifests itself in the OT alone, the socalled 'rewritten Bible', and the use of the OT by NT writers provides the methodological framework for this study. Christopher Stanley comments that 'within the Jewish sphere ... a long-standing tradition allowed for repeated reinterpretation and even rewriting of certain parts of the biblical record so as to draw out its significance for a later time.' 3 In another examination of Paul's use of Scripture, Richard Hays argues

1 Robert S. Snow, 'Daniel's Son of Man in Mark: A Redefinition of the Earthly Temple and the Formation of a New Temple Community' (PhD Dissertation, University of Manchester, 2007). Supervisor: Dr. Kent E. Brower

2 Morna D. Hooker, The Son of Man in Mark: A Study of the Background of the Term 'Son of Man' and Its Use in St. Mark's Gospel (London: SPCK, 1967): 192.

3 Christopher D. Stanley, Paul and the Language of Scripture: Citation Technique in the Pauline Epistles and Contemporary Literature (SNTSMS 69; Cambridge: Cambridge University Press, 1992): 352. 
that the OT functions as a metaphor in Paul's intertextual reflections. ${ }^{4}$ Specifically, ' $\ldots$ the great stories of Israel continue to serve for him as a fund of symbols and metaphors that condition his perception of the world, of God's promised deliverance of his people, and of his own identity and calling. ${ }^{5}$ The work of Hays and Stanley highlights some of the important features of the ways in which the OT functions in and is used by Paul. This methodology is applied to Mark's use of the Danielic SM.

The Marcan SM has a number of specific associations or, in the words of Stanley, evinces 'interpretative renderings' which when viewed in light of Daniel 7, form a connected thematic sequence despite the lack of exact linguistic correspondence with the Danielic SM phrase, 'one like a son of man'. For instance, in the first two appearances of the SM, he manifests the divine presence "upon the earth' $(2: 10,28)$. Although this manifestation is not evident in Daniel 7 , it can be considered a natural corollary of his association with Yahweh's presence in the heavenly temple. The SM forgiving sin and exercising authority over sabbath are prerogatives of Yahweh.

Finally, in order to ascertain fully the significance of the interpretative rendering of the SM in Mark, it is crucial to examine the SM sayings in their own narrative contexts, and even more broadly, to determine how these narratives contribute to the development of Mark's story. As Jens Schröter puts it, the '... designations applied to the main character Jesus have to be interpreted in connection with the narrated events.' ${ }^{6}$ It is for this reason that the work follows Mark's presentation of the SM sayings beginning with Mark 2:10 and concluding with 14:62. Likewise, Hooker analyses each saying as it appears in Mark and concludes at the end of her investigation that 'Mark's pattern of "Son of man" sayings is revealed ... as a logical and coherent whole.'7

The thesis begins by examining the Danielic SM and argues that he has a priestly status and is present in the heavenly temple with

4 Richard B. Hays, Echoes of Scripture in the Letters of Paul (New Haven/London: Yale University Press, 1989).

5 Hays, Echoes, 16.

6 Jens Schröter, 'The Son of Man as the Representative of God's Kingdom: On the Interpretation of Jesus in Mark and Q' in Jesus, Mark, and Q: The Teachings of Jesus and Its Earliest Records, ed. M. Labahn and A. Schmidt (JSNTSup 214; Sheffield: Sheffield Academic Press, 2001): 34-68 (46).

7 Hooker, Son of Man, 182. 
Yahweh, the Ancient of Days. The heavenly myriads' presentation of the SM before Yahweh echoes the presentation of Aaron and his sons before the divine presence in the earthly tabernacle. The priestly SM as a symbol for faithful Israel reconnects the persecuted holy ones with Yahweh's presence since the temple, his earthly dwelling, has been desecrated.

Before determining Mark's interpretative rendering of the Danielic $\mathrm{SM}$, the thesis examines the likewise interpretative rendering of the Danielic SM in the Similitudes and 4 Ezra. This enables one to realise what is 'in the air' regarding interpretative possibilities of the Danielic SM around the time of the composition of Mark's Gospel. In the Similitudes, the SM is in the heavenly temple as in Daniel 7 but now executes prerogatives of Yahweh, such as judgement, and is worshipped along with Yahweh himself. Similarly, in 4 Ezra, the SM destroys Israel's enemies from the heavenly temple which in Daniel 7 is implicitly a function of Yahweh.

The first two appearances of the SM in Mark's first section, 1:14 $8: 21$, express that the SM is a vehicle of the divine presence. This status is demonstrated in the SM's authority to forgive sins and to exercise Yahweh's dominion over sabbath. Regarding the latter, the presence of the SM enables the disciples to execute a duty which only the priests are permitted to do on the sabbath and in the temple. The $\mathrm{SM}$, then, appears to be redefining the sacred space of the temple around himself.

In Mark's second section, 8:27-10:45, the SM is a suffering figure who will eventually die. However, after considering the passionresurrection predictions, the ransom saying in 10:45, and the cup saying in 14:23-24, the SM's redemptive suffering and death leads to the formation of a new temple community. This is a natural development of the SM's redefinition of the temple's sacred space. In light of the foregoing, it is no coincidence that the temple leadership is the dominant group that resists the SM and ultimately brings about his death.

Two sayings from Mark's third section, 11:1-16:8, and one from his second section focus upon the 'vindication' of the SM $(8: 38 ; 13: 26$; and 14:62). Each of these passages depicts the coming of the priestly SM with the heavenly temple and, as in Daniel 7, this coming results in judgement for the SM's adversaries, specifically, for the scribes, elders and chief priests along with their temple institution. This manifestation 
of the SM parallels the pattern in the Similitudes and 4 Ezra in which the SM metes out judgement from his heavenly abode. The Marcan future SM sayings function as a fitting denouement for the SM who begins his ministry by redefining the locus of God's presence and then suffers at the hands of those who are traditionally the keepers of this sacred presence. Accordingly, at his future vindication, the exalted priestly SM executes judgement upon the temple leaders. This judgement and the formation of the new temple community begins to find fulfilment in the final two chapters of Mark: the rending of the temple veil anticipates the SM's final judgement of this structure while the command that the disciples meet Jesus in Galilee marks the beginning of the formation of the new temple community once the suffering SM has risen from the dead. 